Volume 12 Number 4, October-December 2018: pp. 307-328. Copyright (c) 2018 FIAT JUSTISIA. Faculty of Law, Lampung University, Bandarlampung, Lampung, Indonesia. ISSN: 1978-5186 | e-ISSN: 2477-6238.

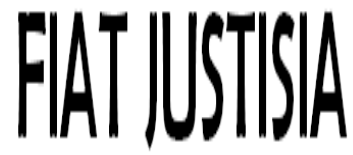

Fiat Justisia is licensed under a Creative Commons Attribution 4.0 International License, which permits unrestricted use, distribution, and reproduction in any medium, provided the original work is properly cited.

\title{
Reviving the Broad Guidelines of State Policy (GBHN) as the Product of People's Consultative Assembly (MPR) in the Presidential Government System in Indonesia
}

\author{
Yusdiyanto \\ University of Padjajaran, Indonesia \\ yusdiyanto@gmail.com
}

\begin{abstract}
The research aims to enlight the overview about the urgent of the Broad Guidelines of State Policy (GBHN) as the product of the People's Consultative Assembly (MPR) by using the dogmatic approach. The amendment of the 1945 Constitution has changed the Indonesian constitutional system. According to the article 2 paragraph (1) of the 1945 Constitution, highest authority remains in the hands of the people and is carried out according to the Constitution. The constitutional design of the Indonesian government system is presidential. However, the implementation often reaps many obstacles and problems, the consequences of amendments, eliminating the authority of the People's Consultative Assembly (MPR) in terms of electing the President and Vice President, and determining the Broad Guidelines of State Policy (GBHN). MPR is no longer placed as the highest institution of the country and (the perpetrators negative meaning: of popular sovereignty. The Constitution which is the holder of popular sovereignty in the practice adheres to a clear and strict understanding of the separation of powers. Like in the legislative field there are People's Consultative Assembly (MPR), House of Representatives (DPR) and Regional Representative Board (DPD); in the executive field there are Presidents and Vice Presidents elected by the people; in the judicial sector there are the Supreme Court, the Constitutional Court and the Judicial Commission; in the field of financial supervision there is a Indonesian Supreme Audit Institution (BPK). Changes in the position, function and authority of the MPR have implications for the emergence of the National Development Planning System and the National Long-Term Development
\end{abstract}


Plan which became the authority of the elected President. The President that won the election as a basic guidelines for implementing development as the replacement of the GBHN.

Keywords: System, Government, and Constitution

How to Cite: Yusdiyanto, "Reviving the Broad Guidelines of State Policy (GBHN) as the Product of People's Consultative Assembly (MPR) in the Presidential Government System in Indonesia”, Fiat Justisia, 12 (4), (2018).

DOI: https://doi.org/ 10.25041/fiatjustisia.v12no4.1328

\section{A. Introduction}

Indonesia as the developing country requires a concrete development direction to realize the development that has an orientation to the welfare of the people as the purpose of the country which is stated in the Preamble of the 1945 Constitution of the Republic of Indonesia (UUD).

The amendment of the 1945 Constitution, has shifted the pendulum of the law formation, which was originally a heavy executive and now shifting to a full authority of the legislative institution. The strengthening of the presidential system gives the legitimacy consequences of the President to determine the policy in determining the directions of the development of Indonesia in the future.

Benny K Harman ${ }^{1}$ stated that the result of the amendment of the 1945 Constitution, the President should not compromise with the parties in overhauling the cabinet. The reason is that Indonesia does not follow the conventional presidential system but the presidential system which has undergone purification. By the existence of the purification, the President is directly elected by the people, the length of service remains 5 years, and the House of Representative could not bring the President down. Although the dynamic of the state administration has undergone a shift, the ideals of the nation and the state contained in the Constitution remain the same; to protect all the people, educate the life of the Nation, and promote the general welfare of the people.

The presence of Broad Guidelines of State Policy (GBHN) in the structure of the state which was began with the Declaration of the Vice President No. X dated on the October 20th, 1945, stating that the workers agency together with the President, set the Broad Guidelines of State Policy (GBHN). Along with the dynamic changes of the State, in the era of the new

1 Benny K Harman, Kabinet dan Purifikasi Sistem Presidensial, in http://www.unisosdem.org/article_detail.php?aid=8094\&coid=3\&caid=21\&gid=3 accessed on January 23, 2016 
order, GBHN was concretized through the realization of the planning model of the Pancasila Democratic Economy in accordance with the Article 33 of the 1945 Constitution which never changed in terms of the substance of the meaning. The Broad Guidelines of State Policy (GBHN) was a guideline for the President to run the wheel of the government. If the President did not follow the guidelines or otherwise violated GBHN, then MPR would dismiss the President. GBHN became the central instrument manifested in the medium-term development with the Five-Year Development Plan (Repelita). The Five-Year Development Plan (Repelita) was used as the elaboration of the GBHN in the early period of Soeharto regime until 1998.

The economic crisis that hit Indonesia in 1997 gave the fact that the new order conception of Repelita only prioritized the economic growth and was not balanced by a democratic and fair of the social, political, and economic life. The vulnerable of the economic development fundamental, the implementation of the nation that was bureaucratic and tended to corrupt, and also undemocratic has caused the monetary and economic crisis that almost continued by the concerned moral crisis.

By the time of the amendment of the 1945 Constitution in the past, GBHN was no longer needed as the consequence of change related to the basic change in the system of the development implementation. While the President was directly elected by the people, then GBHN was no longer used as the guideline of the President in arranging the development plan. In order to ensure that the development activities run effectively, efficiently and targeted, the planning of National Development which was determined in the Regulation No 25 on 2004 of the System of the National Development Planning was needed. The regulation contained the implementation of the macro planning of all function of the government including all fields of life integrated in the Territory of the Republic of Indonesia. ${ }^{2}$ The Planning of the National Development has resulted: a. long-term development plan; b. medium-term development plan; and c. annual development plan. ${ }^{3}$ After that, it was followed up with Law No. 17 on 2007 of the National LongTerm Development Plan for 2005-2025.

On the other hand, the existence of the national development plan has recently been debated because of the stagnation in the development, and no check and balance mechanism is implemented by MPR to control the President in carrying out the National Development. As the results of the National Work Meeting of PDI-Perjuangan Party at the beginning of 2016, it gave an attitude statement and recommendations to restore the authority of

\footnotetext{
${ }^{2}$ Article 3 (1) Law No. 25 on 2004 of the System of the National Development Planning

${ }^{3}$ Ibid.
} 
the MPR to re-establish the Broad Guidelines of State Policy (GBHN). ${ }^{4}$ Through the Secretary-General of the PDI-P Central Executive Board, Hasto Kristiyanto said that the National Development Planning was needed to direct and oversee the political policies of the government to remain one way and one direction. "Such development pattern must contain the elaboration and realization of the Trisakti conception". 5

Even in the recent time, the romanticism towards the Broad Guidelines of State Policy (GBHN) has become a thematic idea and is increasingly widespread; the view of GBHN is more successful than the long-term development plan. Directed and continuous development and the government are not working. Bringing back the Broad Guidelines of State Policy (GBHN) is urgently needed in terms of Indonesian Development which were felt lost. The need to bring back GBHN is triggered because of disappointment felt by some people related to the development which output and outcome cannot run by what is mandated by the Constitution. The development planning is seen as being too emphasized to the limited perspective of the President or the elected Regional Head, resulting in a disparity in the development process between the central and regional government.

In that situation, Saldi Isra asked some parties to be not in a rush in determining to bring back the Broad Guidelines of State Policy (GBHN) because it will influence the existing government system. It is doubtful that GBHN which is determined by MPR will re-confuse the government nowadays, the presidential system should be left and moves to parliamentary. "By bringing back GBHN, it means that putting the People's Consultative Assembly as the highest institution in the country. It is across the existing presidential system that we refer to"7. Indonesia nowadays has some instruments in planning the development; through medium-term development plan and long-term development plan. Therefore, the improvement done should focus more on the existing instrument. ${ }^{8}$ Then Deputy Secretary-General of PDI-Perjuangan Ahmad Basarah said the reason for PDIP wanted to restore the MPR's function to regulate the Broad Guidelines of State Policy (GBHN) because PDI-Perjuangan considered

\footnotetext{
${ }^{4}$ https://m.tempo.co/read/news/2016/01/12/078735286/rakernas-pdip-rekomendasikanmprtetapkan-gbhn, accessed on May 27, 2016, at 02:20.

${ }^{5}$ Ibid.

${ }^{6} \mathrm{http} / / /$ lampung.antaranews.com/berita/287853/pakar-jangan-buru-buru-tentukan-gbhn, accessed on May19, 2018

${ }^{7}$ https://www.elaenews.com/berita/detail/41231/GBHN-Bertentangan-dengan-SistemPresidensial

${ }^{8}$ http://nasional.harianterbit.com/nasional/2016/01/19/53791/0/25/GBHN-BerpotensiLemahkan-Presiden PUSAKO- Kuatkan-MPR
} 
Indonesia seemed to lose its direction in the development and the lack of synchronization between central and regional development. ${ }^{9}$

From the perspective of the pros and cons, the stagnation problem that could be known is why the romanticism of GBHN should be setting it up again. The Pro said that the need for a re-enactment of GBHN was because GBHN was a manifestation of concrete sovereignty regarding its formation process and as a concrete manifestation of strengthening checks and balances. It was the reason why GBHN was more successful than the system of the national development plan. The contrast side said that bringing back GBHN into the authority of MPR would certainly disgrace the presidential system. GBHN which was created top-down would no longer appropriate with the context of state relevance that has been agreed upon by upholding the spirit of regional autonomy. Putting GBHN into the authority of MPR and placing MPR as the highest institution of the country who can evaluate the President is a form of denial of the 1945 constitutional amendment.

\section{B. Discussion}

\section{Indonesian Government System after the Amendment of the Constitution}

The system of government is the way of working of the State Institutions and their relationships with one another. ${ }^{10}$ Sri Soemantri ${ }^{11}$ said that the system of government is the correlation between legislative and executive boards. Ismail Sunny said that the system of the government is a certain system that explains the correlation between the highest state equipment in the country. ${ }^{12}$ Bagir Manan ${ }^{13}$ said that the government system is an understanding which is related to the procedures for the accountability of the government executives in a democratic state. In a democratic state, there is a principle known as geen macht zonder veraantwoordelijkheid which means there is no power without responsibility.

\footnotetext{
${ }^{9}$ Ibid.

${ }^{10}$ Sulardi, Menuju Sistem Pemerintahan Presidensial Murni, Malang: Setara Press, (2012), p. 46.

11 Sri Soemantri, Sistem Sistem Pemerintahan Negara-negara Asean, Bandung: Tarsito, (1976), p. 32.

${ }^{12}$ Ismail Sunny, Mekanisme Demokrasi Pancasila, Jakarta: Aksara Baru cet vi, (1987), pp. 910 .

${ }^{13}$ Bagir Manan, Menyongsong Fajar Otonomi Daerah. Yogyakarta: PSH FH UII, (2001), p. 250.
} 
Rukmana Amanwinata ${ }^{14}$ said that the government system is the correlation between the power of the executive on one side and the power of legislative on the other side. The executive in this context is the executive in narrow meaning which referred to the supreme head of the executive department. Indonesia is a country that adopts the presidential government system. ${ }^{15}$ Abu Daud Busroh, ${ }^{16}$ said that the presidential system is the moment where the President together with the parliament are being elected directly by the societies through a general election. The president has no responsibility to the parliament, therefore the President and the ministry could not be dropped by the parliament. On the other hand, the President could not dismiss the parliament. Both institutions would run the duty in accordance with the stipulation of the Constitution until the end of the length of the service.

In other words, the government system is an order of the accountability relationships upon the implementation of the government between the executive and the legislative (parliament). The governance system is a structure consisting of legislative, executive, and judicial functions that are interconnected, collaborated and influencing one another.

Bagir Manan, ${ }^{17}$ said that the government system running after the amendment of the 1945 Constitution are seen as follows; First; parliamentary rights attached to DPR greatly affect the relationship between the President and DPR. The rights of interpellation and the right of questionnaires, are used as instruments to "disturb" the administration of government, even being used to hold the President hostage to the point of impeachment. As the result, the relation with the President is no longer mainly to achieve the goal of the country but more of being power struggle to demonstrate the strength in order to achieve just a certain political accommodation. It would be more complicated because of the weakness of the parliamentary maturity. This is what is meant by the expression "The President is always in a state of political hostage by political forces. ${ }^{18}$ Second; the order of the government. It has been said that the Prospective President is supported by the party that has their representatives in the House of Representatives (DPR). In line with that, there is no party that has absolute majority portion of seat, therefore the Prospective President (and

\footnotetext{
${ }^{14}$ Rukmana Amanwinata, "Sistem Pemerintahan Indonesia", DIALEKTIKA, 2 (2), (2001), p. 20.

${ }^{15}$ Article4 (1) Indonesia Constitution 1945

${ }^{16}$ Abu Daud Busroh, Ilmu Negara, Jakarta: Bumi Aksara, (2011), p. 63

17 Bagir Manan, "Sistem Pemerintahan RI Sebelum dan Sesudah Perubahan UUD 1945", Presented at the 53rd Scientific Oration of the Padjadjaran University Anniversary, Bandung, September 21, 2010, p. 25.

${ }^{18}$ Ibid.
} 
the vice president) needs the support from more than one party. One of the consequences from the support is the willingness of the presidential candidate to share power with parties or supporting parties - among others ministers as the representatives of the supporting party. This is something that is common in parliamentary systems but seems not right, it does not even exist in the presidential system, as desired by the 1945 Constitution (Article 4 paragraph (1). ${ }^{19}$

Bagir Manan $^{20}$ affirms that the 1945 Constitution requires the presidential system, where: First; the President runs the government (leads and is responsible for government) or is called as the President to hold the real executive power. Second; The President holds the power of a single executive, not a collegial executive, or parliamentary executive. There is no stand-alone cabinet which is responsible to the House of Representatives (DPR) (like in France). Third; The President is not responsible to DPR (as a parliament) and cannot dismiss the DPR.

In the design of check and balances, it becomes inevitable because it is seen as a result of a political process, it is possible to present an oppressive or despotic law. ${ }^{21}$ Bagir Manan ${ }^{22}$ the government system, staatsidee is a presidential system. The presidential system is not merely realized in the form of a President who organizes a government, but includes concepts, mechanisms and supporting instruments that become the equipment of the system. The presidential system is better suited to the district electoral system, both for the simplification of the party and the simple composition of DPR. The simple composition of DPR will simplify the relationship between DPR and the President.

Janedri M. Gaffar said that the representative democracy system created gap between the material of the Constitution content and the communities. ${ }^{23}$ The concepts of statehood in the 1945 Constitution could be seen as the concept of democracy, general election, rule of law, and check and balances in which these concepts are the strange concepts for the public although the real element could be seen in the history of the Indonesian people. ${ }^{24}$

The result of the amendment of the 1945 Constitution has arranged the relationship between certain institutions of the country which refers to

\footnotetext{
${ }^{19} \mathrm{Ibid}$.

${ }^{20}$ Ibid.

${ }^{21}$ Jhon Agresto, The Supreme Court and Constitusional Democracy, Ithaca \& London: Cornel University Press, (1984), p. 31.

${ }^{22}$ Bagir Manan, Op.Cit., p. 3.

23 Janedri M. Gaffar, Demokrasi Konstitusional (Praktik Ketetanegaraan Indonesia setelah Perubahan UUD 1945), Jakarta: Konstitusi Press, (2013), p. 91.

${ }^{24}$ Ibid
} 
the system of controlling and balancing each other (check and balances) so that there will be no institution of the country that will rule more and will be higher in the position compared to the other institutions in the country. ${ }^{25} \mathrm{In}$ line with that, there will be no institution of the country that will implement the authority without having role and participation to the other institutions. ${ }^{26}$ The government system has close relation with the way of the implementation of the governance in a country. In the presidential government system, there are some characteristics that differ it to the parliamentary system, namely: 1) The president and the ministry will have no direct responsibility to the legislative but to the people in the country. ${ }^{27}$ The president will have the prerogative rights in determining the way of the national development and act as the chief of the government and also as the head of the state. ${ }^{28}$

The established democratic system is still running through a representative system which is the best way to form a representative government. ${ }^{29}$ In other words, democracy that can run in accordance with the ideals of democracy itself creates justice and equality in the society and minimizes clashes among various interests. ${ }^{30}$ According to Saldi Isra, ${ }^{31}$, for four times the amendment to the 1945 Constitution (1999-2002), the purification of the Indonesian presidential system was carried out in several forms as follows:

1. Changing the process of the election of the president and the vice president from the election with the representative system (the mechanism of the election in MPR) into direct elections

2. Limiting the periodicity of the service length of the president / the vice president.

3. Clarifying the mechanism of the impeachment of the President and the Vice President.

4. The existence of a prohibition for the president to dismiss the House of Representatives; and

\footnotetext{
${ }^{25}$ Patrialis Akbar, Lembaga-Lembaga Negara menurut UUD NRI Tahun 1945, Jakarta: Sinar Grafika, (2013), p. 238.

${ }^{26}$ Ibid.

27 Jimly Asshiddiqie, Pokok-Pokok Hokum Tatanegara Indonesia Pasca Reformasi, Jakarta: Bhuana Ilmu Populer, (2000), p. 316

${ }^{28}$ Duchack dalam Jimly Asshidiqie, Pergumulan Peran Pemerintah Dan Parlemen Dalam Sejarah (Telaah Perbandingan Konstitusi Berbagai Negara), Jakarta: UI-Press, (1996), p. 82.

${ }^{29}$ Charles Simabura, Parlemen Indonesia-Lintasan Sejarah dan Sistemnya. Jakarta: Raja Grafindo Persada, (2011), p. 23.

${ }^{30}$ Robert W. Hefner (ed), Demokratic Civility: The History and Cross-Cultural Possibility of a Modern Political Ideal. New Brunswick, NJ: Transaction Publisher, (1998), hlm. 6.

${ }^{31}$ Saldi Isra, Pergeseran Fungsi Legislasi (Menguatnya Model Legislasi Parlementer Dalam Sistem Presidensial Indonesia), Jakarta: Rajawali Pers, (2010), p. 63.
} 
5. Updating the mechanism for testing the law.

The article 2 paragraph (1) of the 1945 Constitution, after the amendment, explains that the highest authority remains in the hands of the people and is carried out according to the Constitution. It is means that the implementation of popular sovereignty as part of a democratic system is carried out and spread throughout the body part of the sovereignty constitution is no longer spilled on one institution. ${ }^{32}$ It is means that the constitutional design of the Indonesian government system is presidential.

Scott Mainmawaring stated firmly that the presidential system with the multi-party system is a difficult and dilemma combination. Also, the elected president is not supported by the political party which gains the majority power in the legislative. ${ }^{33}$ According to Jimly Asshiddiqie, the benefit of the presidential system is it could protect the stability of the government. However, the system has weakness regarding it tends to place the executive in most powerful power because of the greatness of power that it could give. Therefore, the setting of the constitution should exist to minimize the negative effect and the weakness which is given since the arising of that presidential system. ${ }^{34}$

After being traced, there are at least three provisions in the 1945 Constitution that become the determinant of the presidential system. It can be seen in the 1945 Constitution, the results of the amendment are: First, the article 4 paragraph (1) states that the President of the Republic of Indonesia holds the power of the government according to the Constitution. Second, the article 6A regulates the procedures of the Presidential election through the general election, while the article 6A verse (2) states that the pair of presidential and vice presidential candidates are proposed by the political parties participating in the general election. The existence of the phrase "joint political party" shows that the constitution-makers realize that to be able to govern the country effectively, a president needs support from the political parties.

This support is formed through a mechanism of the candidate submission that can also be done by the joint political party of the general election. The direction of the legal politics of Article 6A verse (2) actually has a political party direction, which is to prevent the occurrence of a

32 Reza Syawawi dan Khoirunisa Nur Agustyati, "Membunuh Demokrasi Lokal (Mengembalikan Pemilihan Gubernur dan DPRD Provinsi", Jurnal Pemilu \& Demokrasi, (2012), pp.4-6.

${ }^{33}$ Scott Mainwaring, Presidensialisme di Amerika Latin, in the Arend Lijphart, (1995), pp. 117-123; look at to Saldi Isra, Simalakama Koalisi Presidensial artikel dalam Harian Kompas, on November 27, 2008.

34 Jimly Asshiddiqie, Pergumulan Peran Pemerintah dan Parlemen dalam Sejarah: Telaah Perbandingan Konstitusi Berbagai Negara, Jakarta: UI Press, (1996), p. 59. 
multiparty system or simply the process of selecting the president and vice president becomes one of the parties' simplification mechanism, in accordance with the presidential system adopted by the 1945 Constitution. Third, The article 7B that regulates the procedures of dismissal of the President who must follow the mechanism of the impeachment. The article 7C firmly stated that the President could not freeze or dismiss the House of Representatives.

Some experts ${ }^{35}$ say that the main points of the Indonesian government system during the reform period are seen as follows:

1. Form a unitary state with the principle of broad regional autonomy. The territory is divided into provinces.

2. The form of government is a republic, while the system of government is presidential.

3. The president is the head of the state and also the chief of the government. The president and the vice president are elected and appointed by MPR for five years length of service. For the length of service during 2004-2009, the president and the vice president will be chosen directly by the people inside one packet.

4. The ministers are appointed by the president and responsible to the president.

5. The parliament consists of 2 parts, the House of Representatives (DPR) and Regional Representative Board (DPD). The members of the house are also a member of the People's Consultative Assembly. DPR has the power of legislative and the power of supervising the governmental process.

6. Judicial power is implemented by the Supreme Court and the judiciary under it.

In the end, it can be known that the government system resulted from the amendment to the 1945 Constitution, in the current presidential system will be seen as follows:

1. The existence of the recognition of Human rights which is completely contained in the article $28 \mathrm{~A}$ until $28 \mathrm{~J}$ of the 1945 Constitution. It is a result from the recognition and the protection of basic human rights constitutionally, particularly in a political field such as the general election that should be implemented directly, general, independent, secretly, honestly, and fairly in every once in five years. The provisions about the general election and the rotation of the government constitutionally will support the consolidation of the democracy, 
increase the control of the state government, increase the government legitimacy, and improve the rule of law.

2. The existence of a firm regulation concerning the accountability of the government is explicitly stated in article 4 verse (1), article 20 verse (1), and article 24 verse (1).

3. The adoption of the distribution of the power principle.

4. The affirmation of check and balances principle which is reflected in the article $24 \mathrm{C}$, article 13 verse (1), article 13 verse (3), article 15, article 7A, article 20 verse (2), and article 24 B of the 1945 Constitution after the amendment.

5. The adoption of the rule of rotation principle and the regular and direct election system is regulated and determined in the article $22 \mathrm{E}$ verse (3) of the 1945 Constitution.

6. The implementation of people's sovereignty and the power of the government should obey the law which is arranged in the article 1 verse (2), article 1 verse (3), article 4 verse (1), of the 1945 Constitution after the amendment, and

7. The limitation of the presidential constitutional power is included in article 5 verse (1), article 7C, article 11 verse (1), article 13 verse (2), article 13 verse (3), article 14 verse (1), article 14 verse (2), article 15 and article 16 of the 1945 Constitution.

As a country that firmly adheres to the presidential government system in its implementation, it often reaps many obstacles and problems, one of which is when GBHN is pushed to be restored. The enactment of the GBHN can cause the presidential system to be damaged. The President must again be responsible for the development that has been carried out to the MPR as the institution that made GBHN itself. On certain thing such as the presidential election, the president has no responsibility to the MPR but has a responsibility to the people directly.

The result that could be seen as the existence of GBHN will limit the president because the president has the authority to implement the content of GBHN only, not as the president completely who implement the real development programs. It means that by the existence of GBHN, the political pressure is growing unhealthily for the president because the president is unable to be creative and independent in planning and implementing the development for the country.

\section{MPR as non-High Institution of the State}

The constitution has a role in maintaining the essence of the state existence from the influence of the development of the dynamic change. Therefore, the ideal constitution is the one that is the result of the adjustment 
and the perfection to follow all development, particularly things related to the willingness of people's heart. ${ }^{36}$

Before the amendment of the 1945 Constitution, the position of MPR as the High Institute of the state is a form of accommodation from the practice of governance that exists in the environment of the communist countries such as Uni Soviet and China. The position of MPR accommodated the elements of the governance conception which is combinative between the traditions of western liberalism and eastern socialism. The elements of membership of MPR also reflects the spirit of the House of Representatives (DPR) and also Regional Delegates and Group Delegates. ${ }^{37}$ If it is seen from the perspective of the governance, in the present time, the president is not mandated by MPR but mandated by the people directly, which means that it has no causal relation between the president and MPR besides the problems of Hippocratic oath and the inauguration.

The 1945 Constitution firmly adopts the principle of popular sovereignty (volksouvereiniteit). ${ }^{38}$ The alteration of the position, duty, and the authority of MPR according to the 1945 Constitution ended with the loss of the authority from MPR to form the Provisions of MPR which strictly set to the outside such as establishing the Broad Guidelines of State Policy (GBHN). Also, when MPR no longer establishes GBHN to be implemented by the president, then it is the time for the president to prepare his working program based on the 1945 Constitution.

The article 1 verse (2) of the 1945 Constitution said that "Sovereignty is in the hands of the people and is carried out according to the Constitution".

These changes clearly state that the MPR is no longer the highest institution and no longer the institution of the people's sovereignty. The executor of popular sovereignty is then handed over to every institution that carries out the political tasks of the state (not including the judicial power), and they must submit and be responsible to the people. ${ }^{39}$ The retention of the People's Consultative Assembly (MPR) in the state institutional structure is a

\footnotetext{
${ }^{36}$ A.M. Fatwa, "Potret Konstitusi Negara Pasca Perubahan UUD 1945", Paper presented in the Convention on National Law: UUD 1945 sebagai Landasan Konstitusional Grand Design System dan Politik Hukum Nasional, Jakarta, April 15-16, 2008, p. 1.

37 Jimly Asshiddiqie, Konstitusi dan Konstitusionalisme Indonesia, Jakarta: Sekretariat Jenderal dan Kepaniteraan Mahkamah Konstitusi RI, (2006), p. 168.

38 Ismail Suny, "Amandemen Uud 1945 Dan Implikasinya Terhadap Arah Kebijakan Pembangunan Hukum Nasional", Paper presented at Conference on Direction of Legal Development According to the 1945 Constitution Amendment Results held by BPHN Indonesia Department of Law and Human Rights, Jakarta, Mei 29-31, (2006), p. 21.

${ }^{39}$ Ni'matul Huda, Lembaga Negara dalam Masa Transisi Demokrasi, Yogyakarta: UII Press, (2007), p. 96.
} 
special characteristic of Indonesia because no other country has a similar institution.

As it is seen in Article 6A of the 1945 Constitution of the Republic of Indonesia, President and Vice President are elected together by the people, so that the president has no direct response to the MPR. The alteration of MPR authority informing the formation of MPR provision that is acceptable for the outside, also bring the alteration of position and the status of the low of the MPRS Provision and MPR Provision in the hierarchical order of the Constitutional regulation.

In practice, the authority to determine GBHN and elect the President and the vice president are two important things to be put in the provision of MPR. Therefore, in the recent time, while the authority of MPR to arrange GBHN no longer exist, then the authority to arrange TAP which is retelling will be dismissed by itself. ${ }^{40}$ Bagir Manan defines the positive law as the compilation of the principle and rules of the written and unwritten law which both of the laws nowadays is being adopted and should generally be or practically affirm by or through the government and the court of the Indonesian country. ${ }^{4}$

The function and the authority of MPR are arranged in the article 3 verse (1), (2), and (3), and article 8 verse (1), (2), and (3) of the 1945 Constitution. The function and the authority are seen as follows:

1. Alter and determine the Constitution,

2. Inaugurate the president and vice president based on the general elections result during a plenary meeting of MPR,

3. Decide the suggestion of DPR based on the Constitutional Court to dismiss the President and Vice President during his term after the President and/or Deputy Presidency were given the opportunity to explain in the MPR Plenary Session

4. Inaugurate the Vice President to become President if the President dies, resigns, is dismissed, or cannot carry out his obligations within his term of services; elect the Vice President from two candidates submitted by the President if there is a vacancy in the position of President within his term of office no later than sixty days.

5. Also, choose the president and the vice president if both of the president and the vice president resign together in terms of their service length, from two couples of the prospective President and Vice-president proposed by the political party or joint political party, the president and

\footnotetext{
${ }^{40}$ Eko Riyadi, "Reposisi Majelis Permusyawaratan Rakyat (MPR) dan Implikasinya terhadap Kedudukan TAP MPR/S Pasca Amandemen UUD 1945”, Supremasi Hukum, 1 (1), (2012), p. 10.

${ }^{41}$ Bagir Manan, Hukum Positif Indonesia (Satu Kajian Teoritik), Yogyakarta: FH UII Press, (2004), p. 1.
} 
vice president will be elected by the result of the majority votes number one and two in the previous election, it will last until the finish of length of service or in no later than 30 days.

The existence of MPR can no longer be said as the highest institution as far as it has been but will only function as an assembly forum with the authorities determined by the Constitution. ${ }^{42}$ Changes in the position, function, and authority of the MPR have implications for the emergence of the National Development Planning System (SPPN) and National Long-term Development Planning (RPJP) as the basic guideline for the implementation of the GBHN replacement development. Because in this case, the Constitution becomes the holder of people's sovereignty which in practice is shared with institutions with clear and strict separation of powers. In the legislative field there are MPR, DPR, and DPD; in the executive field there are Presidents and Vice Presidents elected by the people; in the judicial sector there are the Supreme Court, the Constitutional Court and the Judicial Commission; in the field of financial supervision, there is an Audit Board of Indonesia.

The normative Long-term Development Planning (RPJP) substantively equals to GBHN in the new order. The more value possessed by development planning systems and documents in the reform era is the opportunity for the regions to be able to explore the various potentials and advantages of their respective regions, to synergize with the "master plan" contained in the RPJP to achieve the objectives mandated by the constitution. Thus, the urgency to revive the GBHN is not justified, because its existence has been realized in RPJPN. ${ }^{43}$

\section{Abandonment of GBHN in Presidential Government Systems}

Constitutionally, it is economical for the writer to return the GBHN in the 1945 Constitution which will have implications for strengthening the MPR position in the constitutional structure, which might be seen as colliding with the Presidential system adopted in the 1945 constitutional amendments. Paulus Israwan Setyoko ${ }^{44}$ said that the Broad Guidelines of State Policy need not be re-implemented because the principle is the same as

\footnotetext{
42 Jimly Asshiddiqie, Konstitusi dan Konstitusionalisme Indonesia, Jakarta: Sekretariat Jenderal dan Kepaniteraan Mahkamah Konstitusi RI, (2006), p. 171.

${ }^{43}$ Mudiyati Rahmatunnisa, "Sistem Perencanaan Pembangunan Nasional (SPPN), Garis-Garis Besar Haluan Negara (GBHN) dan Peran Majelis Permusyawaratan Rakyat (MPR)", Presented at the National Conference on the Indonesian State System, Thursday, April 25, 2013.

${ }^{44}$ http://www.pusakaindonesia.org/perlukah-gbhn-diberlakukan-kembali/, accessed on May 22, (2017), at 10:50 GMT
} 
the Medium-Term Development Plan (RPJM), which is a problem now, the RPJM has never been socialized to the lower levels.

The position of GBHN is a presidential system if it is seen in the perspective of state law, then GBHN in a presidential system cannot be combined. Although this has been applied in the Indonesian state administration practice for 32 years. From the experience of making the GBHN as a basis for a President in the administration of the State and development, it is seen as a mistake throughout the history of the Indonesian state administration. In a presidential system, a president holding the highest power of the State in carrying out his administration a president is only subject to the constitution as the basis of the direction in the administration of the State.

Reviving GBHN is a denial of presidential systems. It is because during the old ordinal regime and the new order, GBHN is a manifestation of parliamentary supremacy, so in constitutional theory, it is not justified to be applied in presidential systems. In other words, it directly causes government instability, besides the President must carry out parliamentary/legislative orders, in this case, the MPR in forming GBHN. Thus, it cannot be denied if this is true that the GBHN will be returned in the 1945 Constitution will trigger a conflict between the President and the MPR when the President leaves the path set by the parliament as regulated in the GBHN.

The willingness to revive and restore the authority of formulating GBHN to MPR is a form of the spirit of parliamentary and is also a regression from the consolidation of Indonesia's constitutional democracy. The constitutional implications if GBHN is included in the 1945 Constitution are: First, the bearer of GBHN discourse believes that the State's direction will not only regulate the direction of development and government but also regulate the pattern of relations between other state institutions. MPR will be involved in regulating the President in the executive area, the Supreme Court and the Constitutional Court in the judicial region and the relations of central and regional government. Second, GBHN is planned to contain the direction of the State regarding the development and the governance that must be carried out by the elected President. The moment when people have directly elected the president and vice president means that the president only will run the program offered and will be responsible to the people of the country not to the representative institution like MPR. Third, the arrangement of GBHN if it is true to be outlined in the form of MPR's stipulation, it will shift the presidential government system into parliamentary supremacy because MPR's provisions are adjusting.

Besides that, the Implications of the Fulfilment of the President's Position through Direct Election eliminated GBHN in the 1945 Constitution 
structure. GBHN as a work reference that was previously set by MPR was no longer needed because the president who won the election actually determined the government's work direction. According to Panmohamdfaiz, he said that he would return GBHN in the Constitution because it was originated from the root of the problems in Indonesia's development that were not directed and sustainable, the existence of a romance towards GBHN that remained alive until the present time. The drafting of GBHN by MPR will only be compatible with the constitutional system before the 1945 constitutional amendment. ${ }^{45}$

In the perspective of constitutional law, the arrangement of GBHN or other terms will have no small derivative implications especially, if the results are poured into the MPR's stipulations. The presence of GBHN is feared to be not in line with the fundamental objectives of the amendment to the 1945 Constitution in the reform era, namely strengthening the presidential government system and affirming the separation of state power.

\section{The Amendment of the 1945 Constitution and the Agreement of GBHN Elimination}

In the practice of state dynamics before the amendment, the 1945 Constitution which is the highest norm of regulation has many irregularities and abuse. The Old Order and the New Order Regime always indoctrinated the people with the sacralization of the constitution, by placing the 1945 Constitution as well as the holy book. The authoritarian attitude and behavior of the Old Order and New Order regimes or the sacralization of the constitution made most Indonesians lose the guts to question the 1945 Constitution. ${ }^{46}$ It is because the results of the amendment will determine the fate, journey and national and state life in the future. ${ }^{47}$

In the process of the 1945 constitutional amendment from 1999-2002, there were five commitments agreed upon by the MPR-RI ad-hoc committee. The five commitments are not changing the opening of the 1945 Constitution, maintaining the Unitary State of the Republic of Indonesia, the explanation about the 1945 Constitution is being abolished, the amendment to the 1945 Constitution is carried out by addendum, and the last is to reinforce the Presidential administration system. The basic agreement to affirm the presidential government system is meant to strengthen the

\footnotetext{
${ }^{45}$ https://panmohamadfaiz.com/2016/05/20/gbhn-dan-haluan-ketatanegaraan/\#more-1461 accessed on May 22, (2016), at 03:15

46 Novel Ali, "Amandemen UUD 1945 sebagai Syarat Menuju Civil Society", Paper presented at the National Conference: Mengkritisi Sakralisme Konstitusi dan Kekuasaan sebagai Upaya Penguatan Civil Society, Yogyakarta, (1999), p. 1.

47 Udiyo Basuki, "Amandemen Kelima Undang-Undang Dasar 1945 sebagai Amanat Reformasi dan Demokrasi”, Panggung Hukum, 1 (1), (2015), p. 7.
} 
stability and the democracy of the government adopted by the Republic of Indonesia based on what have been chosen by the founding fathers in 1945 . Therefore, the writer delivers some opinions from the formulator of the amendment to the 1945 Constitution (member of the Ad Hoc III / I MPR Working Committee), Related to MPR in arranging and settling GBHN and not requiring GBHN in the presidential government system, are said as follows:

a. Prof. Dr. Afan Gaffar, M.A., ${ }^{48}$ said that MPR is a joint session between the House of Representatives and the Regional Representative Council that has no legislative power. The duties of MPR are no longer choosing the President and vice president, assigning GBHN, and accepting the response from the president. It is a consequence when there is an election of the president and the vice president that is adopted directly from the constitution. GBHN is a platform of the party that wins the election, and it will be continued by the platform of the prospective president that win the presidential chair.

b. Hamdan Zulpa ${ }^{49}$ if someday the President is elected directly by the people, then it is seen as something false. President should obey the broad guidelines of the state policy which is determined by MPR because the people directly elect the president. President before being elected by the people and make a campaign on himself, then he should make his programs. By that programs then the society will choose the president. So in time, when we change or amend the other article about the process of the president's election. Then, about the authority of determining GBHN, according to the fraction, it needs to be related to the process of the presidential election. In the formula of the presidential election, it is assumed that the president is elected directly by the people. Therefore, MPR defines GBHN, and the president himself will make his programs. ${ }^{50}$

c. Bagir Manan, ${ }^{51}$ if the president has already been elected directly, then GBHN is no longer needed. Moreover, MPR also will not be needed anymore. The reason is that when the president is directly elected, the president will not be responsible to the MPR. That possibility could happen because when we talk about the amendment of the Constitution,

\footnotetext{
48 Afan Gaffar, Naskah Komprehensif Perubahan Undang-Undang Dasar Negara Republik Indonesia Tahun 1945 Latar Belakang, Proses, dan Hasil Pembahasan, 1999-2002, Jakarta: Sekretariat Jenderal dan Kepaniteraan Mahkamah Konstitusi, (2010), p. 543.

${ }^{49}$ Hamdan Zulpa, Naskah Komprehensif Perubahan Undang-Undang Dasar Negara Republik Indonesia Tahun 1945 Latar Belakang, Proses, dan Hasil Pembahasan, 1999-2002, Jakarta: Sekretariat Jenderal dan Kepaniteraan Mahkamah Konstitusi, (2010), p. 118.

${ }^{50}$ Ibid., p. 229.

${ }^{51}$ Bagir Manan, Naskah Komprehensif Perubahan Undang-Undang Dasar Negara Republik Indonesia Tahun 1945 Latar Belakang, Proses, dan Hasil Pembahasan, 1999-2002, Jakarta: Sekretariat Jenderal dan Kepaniteraan Mahkamah Konstitusi, (2010), p. 153.
} 
there are some urgent things and there are some cases that need to think well.

d. Theo L. Sambuaga, ${ }^{52}$ MPR is placed as the non-permanent body which has daily implementers like the two bodies, namely regional representatives and regional delegates as well as people's representatives, so the MPR's function is really a function that is placed on the very basic things namely the institution that can determine and amend the 1945 Constitution. Related to the suggestion about President where the people directly elect the president. So it is not that MPR chooses the president although MPR is a representative from the society, it is because the process will be more democratic and legitimate. Therefore, by concerning that thing, GBHN which is created by MPR is no longer needed..$^{53}$

e. Zain Badjeber, ${ }^{54}$ said that GBHN is no longer needed when the president has already been elected directly. It is not that if GBHN is defined as the pattern of the national development pattern, then GBHN is needed. Therefore, it depends in the future what we meant by something we want from GBHN.

f. Jacob Utama, ${ }^{55}$ said that we truly do not need GBHN. The policy of ruling the country becomes the authority from the elected president. The guidance from MPR RI is no longer needed too because there is no need for benchmarks from MPR so that the President will no longer be able to be dismissed due to policy differences. The differences of opinion in the policy sometimes happen between the MPR and the President. So that those who can bring down the President later are matters relating to violations of the law, violations of the Constitution.

g. Rully Chairul Azwar, ${ }^{56}$ said several things, first: if we have the willingness to elect the president directly, then GBHN will not be needed anymore. Second, the president responsibility is not needed anymore because if the performance is bad, the president will not be elected anymore in the future.

52 Theo L. Sambuaga, dalam Naskah Komprehensif Perubahan Undang-Undang Dasar Negara Republik Indonesia Tahun 1945 Latar Belakang, Proses, dan Hasil Pembahasan, 1999-2002, Jakarta: Sekretariat Jenderal dan Kepaniteraan Mahkamah Konstitusi, (2010), p. 220.

${ }^{53} \mathrm{Ibid}$.

${ }^{54}$ Zain Badjeber, Naskah Komprehensif Perubahan Undang-Undang Dasar Negara Republik Indonesia Tahun 1945 Latar Belakang, Proses, dan Hasil Pembahasan, 1999-2002, Jakarta: Sekretariat Jenderal dan Kepaniteraan Mahkamah Konstitusi, (2010), p. 252.

55 Jacob utama, Naskah Komprehensif Perubahan Undang-Undang Dasar Negara Republik Indonesia Tahun 1945 Latar Belakang, Proses, dan Hasil Pembahasan, 1999-2002, Jakarta: Sekretariat Jenderal dan Kepaniteraan Mahkamah Konstitusi, (2010), p. 340.

${ }^{56}$ Rully Chairul Azwar, Naskah Komprehensif Perubahan Undang-Undang Dasar Negara Republik Indonesia Tahun 1945 Latar Belakang, Proses, dan Hasil Pembahasan, 1999-2002, Jakarta: Sekretariat Jenderal dan Kepaniteraan Mahkamah Konstitusi, (2010), p. 393. 
h. Anthonius Rahail ${ }^{57}$ said that the Broad Guidelines of the State Policy that has existed while the president could be directly elected, should not need to be adopted again. On the other hand, for the need of working guideline which is set up by the Assembly for the President as the mandate, then it still needs to be adopted so that the direction and the spirit of the development done by the president will always be in the right track.

i. Affandi ${ }^{58}$ said that it is better to keep hold strictly that MPR could stipulate the state direction in the broad guidelines by knowing the reason that GBHN is still needed regarding integrity, resolution, integrality, and the continuity of national development. Moreover for Indonesia as a developing country with the diversity in all aspects. Then, the existence of GBHN would prevent the misuse and mislead and also prevent from the implementation of the government based on certain people's willingness and for the need of a certain ruler of the country.

j. Soedijarto, ${ }^{59}$ it is better if MPR still has the duty and the authority to arrange and determine GBHN as the strategy of national policy. The reason is that, if the president comes from the certain party, this could be explained by Mr. Happy the reason why people trust a little less to the party. It is said that if the President makes the GBHN, it will reflect the needs of the supporting party.

\section{Conclusion}

The amendment of the 1945 Constitution has changed the position, duty, and the authority of the People's Consultative Assembly (MPR) that also deletes the authority of MPR in forming the provisions of the MPR which is set up outside, like establishing the Broad Guidelines of State Policy (GBHN). The idea of whether or not the GBHN needs to be considered rationally, cleverly and measurably and with a democratic perspective by concerning the social political and legal dimensions that are developing. In the presidential system of the government, the presence of the general election for electing the President will make the President has no direct responsibility to the MPR but the society.

The implication of the governance, if GBHN is forced to be applied in the future, is: the first, the bearer of GBHN Discourse will think that the broad guideline will not only rule the development and the government of

\footnotetext{
57 Anthonius Rahail, Naskah Komprehensif Perubahan Undang-Undang Dasar Negara Republik Indonesia Tahun 1945 Latar Belakang, Proses, dan Hasil Pembahasan, 1999-2002, Jakarta: Sekretariat Jenderal dan Kepaniteraan Mahkamah Konstitusi, (2010), p. 412.

${ }^{58}$ Rully Chairul Azwar, Op.Cit., hlm. 460.

${ }^{59}$ Soedijarto, Naskah Komprehensif Perubahan Undang-Undang Dasar Negara Republik Indonesia Tahun 1945 Latar Belakang, Proses, dan Hasil Pembahasan, 1999-2002, Jakarta: Sekretariat Jenderal dan Kepaniteraan Mahkamah Konstitusi, (2010), p. 523.
} 
the nation but also will rule the relationship pattern that connects the other institutions. MPR will be directly involved in controlling the President in the executive, The Supreme Court and the Constitutional Court in the judicial region and the relation between central and regional government. Second, GBHN will be planned to contain the broad guidelines related to the development and the government that should be implemented by the elected president. While the president and the vice president are being elected directly by the people in the country, they will not be chosen by the representative of the house as being mandated by MPR. The third, the arrangement of GBHN if it is true, will be written regarding the provisions of the MPR and it will shift the presidential government system into the parliament supremacy because the provision of MPR will be regulating.

In the perspective of the constitutional law, the preparation of the GBHN or other terms will have no small derivative implications, especially, if the results are poured into the MPR's stipulations. The presence of GBHN is considered to be not in line with the fundamental objectives of the amendment to the 1945 Constitution in the reform era, namely strengthening the presidential government system and affirming the separation of state power.

\section{A. Book}

\section{Bibliography}

Agresto, Jhon. (1984). The Supreme Court and Constitusional Democracy.

Ithaca \& London: Cornel University Press

Akbar, Patrialis. (2013). Lembaga-Lembaga Negara menurut UUD NRI Tahun 1945. Jakarta: Sinar Grafika

Asshiddiqie, Jimly. (1996). Pergumulan Peran Pemerintah dan Parlemen dalam Sejarah: Telaah Perbandingan Konstitusi Berbagai Negara. Jakarta: UI Press

Asshiddiqie, Jimly. (2000). Pokok-Pokok Hokum Tatanegara Indonesia Pasca Reformasi. Jakarta: Bhuana Ilmu Populer.

Asshiddiqie, Jimly. (2006). Konstitusi dan Konstitusionalisme Indonesia. Jakarta: Sekretariat Jenderal dan Kepaniteraan Mahkamah Konstitusi RI Busroh, Abu Daud. (2011). Ilmu Negara. Jakarta: Bumi Aksara

Duchack in the Jimly Asshidiqie. (1996). Pergumulan Peran Pemerintah Dan Parlemen Dalam Sejarah. Jakarta: UI-Press.

Gaffar, Afan. (2010). Naskah Komprehensif Perubahan Undang-Undang Dasar Negara Republik Indonesia Tahun 1945 Latar Belakang, Proses, dan Hasil Pembahasan, 1999-2002. Jakarta: Sekretariat Jenderal dan Kepaniteraan Mahkamah Konstitusi 
Gaffar, Janedri M. (2013). Demokrasi Konstitusional (Praktik Ketetanegaraan Indonesia setelah Perubahan UUD 1945). Jakarta: Konstitusi Press

Hefner, Robert W. (1998). Demokratic Civility: The History and CrossCultural Possibility of a Modern Political Ideal. New Brunswick: NJ: Transaction Publisher, https://doi.org/10.4324/9781351290609

Huda, Ni'matul. (2007). Lembaga Negara dalam Masa Transisi Demokrasi. Yogyakarta: UII Press

Isra, Saldi. (2010). Pergeseran Fungsi Legislasi (Menguatnya Model Legislasi Parlementer Dalam Sistem Presidensial Indonesia). Jakarta: Rajawali Pers.

Manan, Bagir. (2001). Menyongsong Fajar Otonomi Daerah. Yogyakarta: PSH FH UII

Manan, Bagir. (2004). Hukum Positif Indonesia (Satu Kajian Teoritik). Yogyakarta: FH UII Press

Simabura, Charles. (2011). Parlemen Indonesia-Lintasan Sejarah dan Sistemnya. Jakarta: Raja Grafindo Persada

Soemantri, Sri. (1976). Sistem Sistem Pemerintahan Negara-negara Asean. Bandung: Tarsito

Sulardi. (2012). Menuju System Pemerintahan Presidensial Murni. Malang: Setara Press

Sunny, Ismail. (1987). Mekanisme Demokrasi Pancasila. Jakarta: Aksara Baru

\section{B. Journals and Article}

A.M. Fatwa, "Potret Konstitusi Negara Pasca Perubahan UUD 1945", Paper presented in the Convention on National Law: UUD 1945 sebagai Landasan Konstitusional Grand Design System dan Politik Hukum Nasional. Jakarta, (2008).

Benny K Harman, Kabinet dan Purifikasi Sistem Presidensial, dalam Eko Riyadi, "Reposisi Majelis Permusyawaratan Rakyat (MPR) dan Implikasinya terhadap Kedudukan TAP MPR/S Pasca Amandemen UUD 1945", Jurnal Supremasi Hukum, 1 (1), (2012).

Ismail Suny, "Amandemen UUD 1945 dan Implikasinya Terhadap Arah Kebijakan Pembangunan Hukum Nasional", Paper presented at the Seminar on the Direction of Legal Development According to the 1945 Constitution Amendment Results held by BPHN Ministry of Law and Human Rights Rl, Jakarta, Mei 29-31, 2006.

Manan, Bagir. Sistem Pemerintahan RI Sebelum dan Sesudah Perubahan UUD 1945. Presented at the 53rd Scientific Oration of the Padjadjaran University Anniversary. Bandung, September 21, 2010. 
Mudiyati Rahmatunnisa, "Sistem Perencanaan Pembangunan Nasional (SPPN), Garis-Garis Besar Haluan Negara (GBHN) dan Peran Majelis Permusyawaratan Rakyat (MPR)", Presented at the Indonesian State Administration System National Seminar: Reformulation of the GBHN Model: An Overview of the Role and Function of the Indonesian MPR in the National Development Planning System, MPR Cooperation with Padjadjaran University, Aston Tropicana Cihampelas Hotel, Thursday, April 25, 2013.

Novel Ali, "Amandemen UUD 1945 sebagai Syarat Menuju Civil Society", Paper presented at the National Seminar on Criticizing Constitutional Sacredism and Power as an Effort to Strengthen Civil Society, Yogyakarta, 1999.

Reza Syawawi dan Khoirunisa Nur Agustyati, "Membunuh Demokrasi Lokal (Mengembalikan Pemilihan Gubernur dan DPRD Provinsi", Jurnal Pemilu \& Demokrasi, (2012).

Rukmana Amanwinata, "Sistem Pemerintahan Indonesia", DIALEKTIKA, 2 (2), (2001).

Udiyo Basuki, "Amandemen Kelima Undang-Undang Dasar 1945 sebagai Amanat Reformasi dan Demokrasi", PANGGUNG HUKUM, 1 (1), (2015).

\section{World Wide Web}

http://hitamandbiru.blogspot.com/2011/01/perbandingan-sistem

pemerintahan.html\#ixzz3xcN7M6Sq

http://lampung.antaranews.com/berita/287853/pakar-jangan-buru-buru-

tentukan-gbhn,

http://nasional.harianterbit.com/nasional/2016/01/19/53791/0/25/GBHN-

Berpotensi-Lemahkan-Presiden

http://www.pusakaindonesia.org/perlukah-gbhn-diberlakukan-kembali/

http://www.unisosdem.org/article_detail.php?aid=8094\&coid=3\&caid=21\& gid=3

https://m.tempo.co/read/news/2016/01/12/078735286/rakernas-pdip-

rekomendasikan-mpr

https://panmohamadfaiz.com/2016/05/20/gbhn-dan-haluan-

ketatanegaraan/\#more-1461

https://www.elaenews.com/berita/detail/41231/GBHN-Bertentangan-

dengan-Sistem-Presidensial 